\title{
Leaf Gas Exchange and Oxidative Stress in Sorghum Plants Supplied with Silicon and Infected by Colletotrichum sublineolum
}

\author{
Renata Sousa Resende, Fabrício Ávila Rodrigues, Paulo Cezar Cavatte, Samuel Cordeiro Vitor Martins, \\ Wiler Ribas Moreira, Agnaldo Rodrigues Melo Chaves, and Fábio Murilo DaMatta
}

First, second, and fifth authors: Viçosa Federal University, Department of Plant Pathology, Laboratory of Host-Parasite Interaction, Viçosa, Minas Gerais State, 36.570-000, Brazil; and third, fourth, sixth, and seventh authors: Viçosa Federal University, Department of Biology, Viçosa, Minas Gerais State, 36.570-000, Brazil.

Accepted for publication 28 May 2012.

\begin{abstract}
Resende, R. S., Rodrigues, F. Á., Cavatte, P. C., Martins, S. C. V., Moreira, W. R., Chaves, A. R. M., and DaMatta, F. M. 2012. Leaf gas exchange and oxidative stress in sorghum plants supplied with silicon and infected by Colletotrichum sublineolum. Phytopathology 102:892-898.

Considering the economic importance of anthracnose, caused by Colletotrichum sublineolum, and silicon ( $\mathrm{Si}$ ) to enhance sorghum resistance against this disease, this study aimed to investigate the effect of this element on leaf gas exchange and also the antioxidative system when infected by C. sublineolum. Plants from sorghum line CMSXS142 (BR 009 [Tx623] - Texas), growing in hydroponic culture with (+Si, $2 \mathrm{mM})$ or without $(-\mathrm{Si}) \mathrm{Si}$, were inoculated with $C$. sublineolum. Disease severity was assessed at 2, 4, 6, 8, and 10 days after inoculation (dai) and data were used to calculate the area under anthracnose progress curve (AUAPC). Further, the net carbon assimilation rate $(A)$, stomatal conductance to water vapor $\left(g_{\mathrm{s}}\right)$, internal-to-ambient $\mathrm{CO}_{2}$ concentration ratio $\left(C_{\mathrm{i}} / C_{\mathrm{a}}\right)$, and transpiration rate $(E)$; the activities of superoxide dismutase

with the - Si plants. The values of $A, g_{\mathrm{s}}$, and $E$ were lower upon inoculation of $-\mathrm{Si}$ plants in contrast to inoculated $+\mathrm{Si}$ plants with decreases of 31 and $60 \%$ for $A, 34$ and $61 \%$ for $g_{\mathrm{s}}$, and 27 and $57 \%$ for $E$, respectively, at 4 and 8 dai. For the noninoculated plants, there was no significant difference between the $-\mathrm{Si}$ and $+\mathrm{Si}$ treatments for the values of $A, g_{\mathrm{s}}$, and $E$. The $C_{\mathrm{i}} / C_{\mathrm{a}}$ ratio was similar between the $-\mathrm{Si}$ and $+\mathrm{Si}$ treatments, regardless of the pathogen inoculation. The activities of SOD, CAT, APX, and GR tended to be higher in the $+\mathrm{Si}$ plants compared with the $-\mathrm{Si}$ plants upon inoculation with $C$. sublineolum. The EL significantly increased for $-\mathrm{Si}$ plants compared with $+\mathrm{Si}$ plants. The MDA concentration significantly increased by 31 and $38 \%$ at 4 and 8 dai, respectively, for the -Si plants compared with the +Si plants. Based on these results, Si may have a positive effect on sorghum physiology when infected by $C$. sublineolum through the maintenance of carbon fixation and also by enhancing the antioxidant system, which resulted in an increase in reactive oxygen species scavenging and, ultimately, reduced damage to the cell membranes.
\end{abstract} (SOD), catalase (CAT), ascorbate peroxidase (APX), and glutathione reductase (GR); the electrolyte leakage (EL), and the concentrations of hydrogen peroxide $\left(\mathrm{H}_{2} \mathrm{O}_{2}\right)$ and malondialdehyde (MDA) were determined. The AUAPC was reduced by $86 \%$ for the $+\mathrm{Si}$ plants compared
Additional keywords: acervulus, antioxidant system, photosynthesis, Sorghum bicolor.
Anthracnose, caused by Colletotrichum sublineolum P. Hen, Kabát \& Bubák $(43,46)$, is the most destructive fungal disease of sorghum (Sorghum bicolor [L.] Moench), especially in warm and humid regions worldwide (1). On leaves, the symptoms of anthracnose appear as small circular-elliptical, tan to orange-red to black lesions, especially in the midvein. The lesion size and color are strictly associated with the sorghum genotype (49). Expanded lesions are usually tan in the center, with a distinct reddish purple to brown border (49). Under high humidity, the lesions increase in number, and they cover most of the leaf area when coalescing, resulting in early water deficiency (13). Acervuli with many conidia with dark setae interspersed among them are formed in the center of these tan lesions (1). Complete shoot destruction and yield failure are usually observed in susceptible cultivars under environmental conditions that are favorable for disease development (18).

Plants respond to pathogen infections by activating several mechanisms of defense that redirect large fluxes of carbon derivatives from primary metabolism to secondary metabolism (10). Several studies have shown that the infection by pathogens

Corresponding author: F. A. Rodrigues; E-mail address: fabricio@ufv.br

http://dx.doi.org/10.1094/PHYTO-01-12-0014-R

(c) 2012 The American Phytopathological Society causes a decrease in photosynthetic rates that is usually associated with direct damage to the photosynthetic apparatus $(7,8,14)$ and can result in an increase in excitation energy that exceeds the amount required for photosynthetic metabolism (4). When not properly dissipated, this excess energy can lead to the production of reactive oxygen species (ROS) (3,31), most commonly, superoxide $\left(\mathrm{O}_{2}^{-}\right)$, hydroxyl radical $(\mathrm{OH})$, hydrogen peroxide $\left(\mathrm{H}_{2} \mathrm{O}_{2}\right)$, and singlet oxygen $\left({ }^{1} \mathrm{O}_{2}\right)$ (3). If not quickly scavenged, these ROS can react with unsaturated fatty acids located in the plasma membrane, organellar membranes, and endomembranes, causing lipid peroxidation (39). ROS also can damage the photosynthetic pigments, proteins, and nucleic acids (34). To control the concentrations of ROS and reduce their cytotoxicity, plants have developed a protective antioxidant system that includes small molecules, such as ascorbate, glutathione, flavonoids, and carotenoids, and several antioxidant enzymes (33). The most important antioxidant enzymes involved in this process are superoxide dismutase (SOD), which catalyzes the dismutation of $\mathrm{O}_{2}^{-}$to $\mathrm{H}_{2} \mathrm{O}_{2}$, catalase (CAT), which converts $\mathrm{H}_{2} \mathrm{O}_{2}$ to $\mathrm{H}_{2} \mathrm{O}$ and $\mathrm{O}_{2}$, and the enzymes of the ascorbate-glutathione cycle, such as ascorbate peroxidase (APX), which reduce $\mathrm{H}_{2} \mathrm{O}_{2}$ using ascorbate as the electron donor (33). The oxidized ascorbate is then reduced by reduced glutathione, which is produced from oxidized glutathione, as catalyzed by glutathione reductase (GR) with the consumption of nicotinamide adenine dinucleotide phosphateoxidase (NADPH) (3). 
Although silicon ( $\mathrm{Si}$ ) is not recognized as an essential element for plants, its beneficial effect on plant growth and the resistance to plant diseases is very well documented (15). Application of soluble sources of $\mathrm{Si}$ to $\mathrm{Si}$-deficient soils is a practice that ideally fits in with environmental friendly strategies for sustainable crop production mainly because of the reduction on fungicides spray besides the low cost compared with lime application (15). This element also plays a pivotal role in reducing the damage caused by various types of abiotic stresses in a wide range of plant species (30). However, the role of Si in plant biology is not well understood and attempts to associate the effect of this element with metabolic or physiological activities have been inconclusive thus far. Some studies have reported the association of $\mathrm{Si}$ with antioxidant metabolism in plants under abiotic stress. In wheat plants supplied with Si under flooded conditions, the activities of SOD and APX did not increase, whereas the activities of POX and CAT were dramatically reduced (21). Cucumber plants grown under salt stress and supplied with $\mathrm{Si}$ showed an increase in the activities of SOD, APX, and GR, whereas the CAT activity remained unaltered (51). Similar results were observed in barley plants supplied with Si under salt stress (25). However, more indepth studies are needed to better understand the effects of $\mathrm{Si}$ on the physiology of plants under biotic stress.

Because research demonstrating the effect of $\mathrm{Si}$ on the antioxidative metabolism of sorghum plants infected with $C$. sublineolum is, to the best of our knowledge, lacking in the literature, the purpose of this study was to determine the effect of $\mathrm{Si}$ on the leaf gas exchange and the antioxidative system in sorghum plants when infected by $C$. sublineolum.

\section{MATERIALS AND METHODS}

Nutrient solution preparation. The nutrient solution used in this study was prepared based on Hoagland and Arnon (23), with some modifications, and included the following macronutrients, $3 \mathrm{mM} \mathrm{KNO} 3,0.5 \mathrm{mM} \mathrm{NH} \mathrm{H}_{2} \mathrm{PO}_{4}, 1 \mathrm{mM} \mathrm{MgSO} \mathrm{M}_{4} \cdot 7 \mathrm{H}_{2} \mathrm{O}$, and $2 \mathrm{mM} \mathrm{Ca}\left(\mathrm{NO}_{3}\right) \cdot 4 \mathrm{H}_{2} \mathrm{O}$, and the following micronutrients, $0.30 \mu \mathrm{M} \mathrm{CuSO}_{4} \cdot 5 \mathrm{H}_{2} \mathrm{O}, 0.33 \mu \mathrm{M} \mathrm{ZnSO} \cdot \cdot 7 \mathrm{H}_{2} \mathrm{O}, 11.5 \mu \mathrm{M} \mathrm{H}_{3} \mathrm{BO}_{3}$, $3.5 \mu \mathrm{M} \quad \mathrm{MnCl}_{2} \cdot 4 \mathrm{H}_{2} \mathrm{O}, 0.1 \mu \mathrm{M}\left(\mathrm{NH}_{4}\right) \cdot 6 \mathrm{Mo}_{7} \mathrm{O}_{2} \cdot 4 \mathrm{H}_{2} \mathrm{O}, 50 \mu \mathrm{M}$ $\mathrm{FeSO}_{4} \cdot 7 \mathrm{H}_{2} \mathrm{O}$, and $50 \mu \mathrm{M}$ disodium EDTA. Silicon was supplied as monosilicic acid, which was prepared by passing potassium silicate through a cation-exchange resin (Amberlite IR-120B, $\mathrm{H}^{+}$ form; Sigma-Aldrich, São Paulo, Brazil) (29). Silicon was applied at $2 \mathrm{mM}$ while nonamended $\mathrm{Si}(0 \mathrm{mM})$ served as the control. The addition of monosilicic acid to the nutrient solution did not alter the $\mathrm{pH}$.

Plant growth. Seeds from the sorghum line CMSXS142 (BR 009 [Tx623] - Texas), an anthracnose-susceptible line, were surface-sterilized in $10 \%$ ( $\mathrm{vol} / \mathrm{vol}$ ) $\mathrm{NaOCl}$ for $2 \mathrm{~min}$, rinsed in sterilized water for $3 \mathrm{~min}$, and germinated on distilled watersoaked germitest paper (Fisher Scientific Co., Pittsburgh, PA) in a germination chamber at $25^{\circ} \mathrm{C}$ for 6 days. The germinated seedlings were transferred to plastic pots with one-half strength of the nutrient solution without Si for 7 days. Subsequently, five plants were transferred to new plastic pots containing 5 liters of nutrient solution prepared with or without $\mathrm{Si}$. The aerated nutrient solution was changed every 4 days, and the electrical conductivity and $\mathrm{pH}$ of the nutrient solutions were measured daily. The $\mathrm{pH}$ was maintained at approximately 5.5 by adding $\mathrm{NaOH}$ or $\mathrm{HCl}(1 \mathrm{M})$ when necessary. The plants were grown in a greenhouse with a relative humidity of $65 \pm 5 \%$, temperature of $30 \pm 5^{\circ} \mathrm{C}$, and natural irradiance of $900 \pm 15 \mu \mathrm{mol}$ photons $\mathrm{m}^{-2} \mathrm{~s}^{-1}$, as measured at midday.

Inoculation procedure. A pathogenic isolate of $C$. sublineolum (CNPMS-12) (38) was used to inoculate the plants. This isolate was maintained in glass vials containing potato-dextrose agar (PDA) covered with mineral oil at $4^{\circ} \mathrm{C}$. Pieces of the PDA containing fungal mycelia were transferred to Petri dishes containing oat medium (16). After 3 days, oat medium plugs containing fungal mycelia were transferred to new Petri dishes, which were incubated in a growth chamber at $25^{\circ} \mathrm{C}$ with a $12 \mathrm{~h}$ photoperiod for 10 days. After this time period, the mycelia were carefully removed from the Petri dishes using a rubber policeman, and the Petri dishes were returned to the growth chamber at $25^{\circ} \mathrm{C}$ under continuous light to obtain the conidia. The plants were inoculated with a conidial suspension of C. sublineolum $\left(1 \times 10^{6}\right.$ conidia $\mathrm{ml}^{-1}$ ) at 30 days after emergence (growth stage 30) (18). A total of $20 \mathrm{ml}$ of suspension was applied as a fine mist to the adaxial leaf blades of each plant until runoff using a VL Airbrush atomizer (Paasche Airbrush Co., Chicago, IL). Immediately after inoculation, the plants were transferred to a mist chamber at $25 \pm$ $2{ }^{\circ} \mathrm{C}$ and a relative humidity of $90 \pm 2 \%$ and kept in the dark for $18 \mathrm{~h}$. After this period, the plants were transferred to a greenhouse (temperature of $26 \pm 2{ }^{\circ} \mathrm{C}$, relative humidity of $80 \pm 5 \%$ ) where they remained for the duration of the experiments.

Evaluation of anthracnose severity. The severity was assessed at 2, 4, 6, 8, and 10 days after inoculation (dai) on the fourth and fifth leaves from the top of each plant using the diagrammatic scale proposed by Sharma (42). The area under anthracnose progress curve (AUAPC) for each leaf on each plant was computed using the trapezoidal integration of the anthracnose progress curve over time, using the formula proposed by Shaner and Finney (41).

Leaf gas exchange evaluation. The net carbon assimilation rate $(A)$, stomatal conductance to water vapor $\left(g_{\mathrm{s}}\right)$, internal-toambient $\mathrm{CO}_{2}$ concentration ratio $\left(C_{\mathrm{i}} / C_{\mathrm{a}}\right)$, and transpiration rate $(E)$ were measured for the fourth and fifth leaves from the top of each plant per replication of the treatments. The measurements were conducted at approximately 8 and $12 \mathrm{~h}$ with an infrared gas analyzer (LC pro $^{+}$, Analytical Development Company, Hoddesdon, UK). The mean leaf temperature was $35^{\circ} \mathrm{C}$ during the photosynthetic measurements.

Physiological and biochemical assays. Samples from the fourth and fifth leaves from the top of each plant per replication and treatment were collected at 4 and 8 dai at approximately $12 \mathrm{~h}$. Leaf samples collected from noninoculated plants served as the controls ( 0 dai). The leaf samples were kept in liquid nitrogen during the sampling and then stored at $-80^{\circ} \mathrm{C}$ until the analysis.

Determination of enzymes activities. For the determination of the activities of superoxide dismutase (SOD, EC 1.15.1.1), catalase (CAT, EC 1.11.1.6), ascorbate peroxidase (APX, EC 1.11.1.11), and glutathione reductase (GR, EC 1.8.1.7), a total of $200 \mathrm{mg}$ of leaf tissue was ground into a fine powder in a mortar and pestle with liquid nitrogen. The fine powder was homogenized in an ice bath with $60 \mathrm{mg}$ of polyvinylpolypyrrolidone (PVPP) and the following: for SOD, $1 \mathrm{ml}$ of $100 \mathrm{mM}$ potassium phosphate buffer ( $\mathrm{pH} 7.8$ ), $0.1 \mathrm{mM}$ ethylenediaminetetraacetic acid (EDTA), and $0.1 \%$, vol/vol, Triton X-100; for CAT, $1 \mathrm{ml}$ of $100 \mathrm{mM}$ potassium phosphate buffer ( $\mathrm{pH} 7.0)$ and $0.1 \mathrm{mM}$ EDTA; for APX, $1 \mathrm{ml}$ of $50 \mathrm{mM}$ potassium phosphate buffer $(\mathrm{pH} 7.0)$ and $1 \mathrm{mM}$ ascorbate; and, for GR, $1 \mathrm{ml}$ of $100 \mathrm{mM}$ Tris- $\mathrm{HCl}$ (pH 7.5), $50 \mathrm{mM}$ EDTA, $10 \mathrm{mM}$ isoascorbate, $9 \mathrm{mM}$ 2-mercaptoethanol, and $0.1 \%$ (vol $/ \mathrm{vol})$ Triton $\mathrm{X}-100$. The homogenates were centrifuged at $15,000 \times g$ for $15 \mathrm{~min}$ at $4^{\circ} \mathrm{C}$, and the supernatants were used as crude enzyme extracts. The SOD activity was determined by measuring its ability to photochemically reduce $p$ nitrotetrazol blue (NTB) (20). The reaction was started after the addition of $5 \mu \mathrm{l}$ of the crude enzyme extract to $3 \mathrm{ml}$ of a mixture containing $50 \mathrm{mM}$ potassium phosphate buffer ( $\mathrm{pH} 7.8), 14 \mathrm{mM}$ methionine, $75 \mu \mathrm{M}$ NTB, $0.1 \mu \mathrm{M}$ EDTA, and $2 \mu \mathrm{M}$ riboflavin. The production of formazan blue, resulting from the photoreduction of NTB, was monitored by the increase in absorbance at $560 \mathrm{~nm}$ (20). One unit of SOD was defined as the amount of enzyme necessary to inhibit NTB photoreduction by $50 \%$. The CAT activity was estimated by the rate of $\mathrm{H}_{2} \mathrm{O}_{2}$ decomposition at $240 \mathrm{~nm}$ (22). The reaction was initiated after the addition of $20 \mu \mathrm{l}$ 
of the crude enzyme extract to $3 \mathrm{ml}$ of a mixture containing $50 \mathrm{mM}$ potassium phosphate buffer $(\mathrm{pH} 7.8)$ and $12.5 \mathrm{mM} \mathrm{H}_{2} \mathrm{O}_{2}$. For APX, the reaction was started after adding $20 \mu \mathrm{l}$ of the crude enzyme extract to $3 \mathrm{ml}$ of a mixture containing $50 \mathrm{mM}$ potassium phosphate buffer ( $\mathrm{pH} 7.0$ ), $0.5 \mathrm{mM}$ ascorbate, and $0.1 \mathrm{mM} \mathrm{H}_{2} \mathrm{O}_{2}$. The APX activity was determined by the rate of ascorbate oxidation at $290 \mathrm{~nm}$ (35). The GR activity was determined by the rate of NADPH oxidation at $340 \mathrm{~nm}$. The reaction was initiated after adding $20 \mu \mathrm{l}$ of the crude enzyme extract to a mixture containing $50 \mathrm{mM}$ Tris- $\mathrm{HCl}(\mathrm{pH} 7.5), 10 \mathrm{mM}$ reduced glutathione, $3 \mathrm{mM} \mathrm{MgCl}_{2}$, and $0.15 \mathrm{mM} \mathrm{NADPH}$.

For each enzyme, six separate extractions were performed using samples from each treatment, and each reaction was performed three times. The soluble protein contents of the extracts were measured using the method of Bradford (11).

Electrolyte leakage (EL) assay. A total of $200 \mathrm{mg}$ of leaf tissue was used for the EL assay, which was determined according to the methodology of Lima et al. (27), with few modifications. The leaf tissue was thoroughly washed in deionized sterile water and then left to float on $60 \mathrm{ml}$ of deionized water in sealed glass vials for $4 \mathrm{~h}$ at $25^{\circ} \mathrm{C}$. After this period, the first value of conductivity (reading one) was obtained using a conductivity meter (Tecnopon mCA-150, MS Tecnopon Instrumentação Científica, São Paulo, Brazil). Next, the vials were transferred to an oven for $2 \mathrm{~h}$ at $90^{\circ} \mathrm{C}$ to obtain a new value for conductivity (reading two). The EL, in percentage, was obtained by dividing the value of reading one by the value of reading two.

Hydrogen peroxide $\left(\mathrm{H}_{2} \mathrm{O}_{2}\right)$ assay. A total of $200 \mathrm{mg}$ of leaf tissue was ground into a fine powder using a pestle and mortar with liquid nitrogen. The fine powder was homogenized in an ice bath in $2 \mathrm{ml}$ of $50 \mathrm{mM}$ potassium phosphate buffer ( $\mathrm{pH} 6.5$ ) containing $1 \mathrm{mM}$ hydroxylamine. The homogenate was centrifuged at $10,000 \times g$ for $15 \mathrm{~min}$ at $4^{\circ} \mathrm{C}(24)$, and the supernatant was used to determine the $\mathrm{H}_{2} \mathrm{O}_{2}$. The reaction was initiated after adding $50 \mu \mathrm{l}$ of the supernatant to a mixture containing sulfuric acid, ammonium ferrous sulfate, xylenol orange, and sorbitol in a total volume of $2 \mathrm{ml}$ (19). The samples were kept in the dark for $30 \mathrm{~min}$, and the absorbance was recorded at $560 \mathrm{~nm}$. Control samples (blank) for the color of the reagents and for the sample extracts were prepared concurrently with the test samples and subtracted from the absorbance of each sample.

Lipid peroxidation assay. Oxidative damage to lipids was estimated as the content of the total 2-thiobarbituric acid (TBA)reactive substances and expressed as equivalents of malondialdehyde (MDA), according to Cakmak and Horst (12), with few modifications. Briefly, a total of $200 \mathrm{mg}$ of leaf tissue was homogenized in $2 \mathrm{ml}$ of $0.1 \%$ (wt/vol) trichloroacetic acid (TCA) solution at $4^{\circ} \mathrm{C}$. After centrifugation at $10,000 \times g$ for $15 \mathrm{~min}$, $0.5 \mathrm{ml}$ of the supernatant was reacted with $1.5 \mathrm{ml}$ of TBA $(0.5 \%$ in $20 \%$ TCA) for $20 \mathrm{~min}$ in a boiling water bath. After this period, the reaction was stopped by immersion in an ice bath. The samples were centrifuged at $13,000 \times g$ for $4 \mathrm{~min}$, and the absorbance of the supernatant was recorded at $532 \mathrm{~nm}$. The concentration of MDA formed in each sample was calculated by using the extinction coefficient of $155 \mathrm{mM}^{-1} \mathrm{~cm}^{-1}$.

Experimental design and data analysis. Two experiments consisting of two $\mathrm{Si}$ concentrations $(0$ and $2 \mathrm{mM}$, hereafter referred to as the $-\mathrm{Si}$ and $+\mathrm{Si}$ treatments, respectively) were arranged in a completely randomized design, with ten replications for the leaf gas exchange measurements and six replications for the evaluation of the anthracnose severity and to obtain samples for the EL and biochemical assays. Each experimental unit consisted of one plastic container with 5 liters of nutrient solution and five plants. Data for each variable were pooled based on Bartlett's test. This test was used to verify if the replications from the two experiments were from populations with equal variances. Equal variances across samples are denominated homogeneity of variances. Some statistical tests, for example the analysis of variance (ANOVA), assume that variances are equal across groups or samples and Bartlett's test can be used to verify that assumption. Data were analyzed by ANOVA, and the treatment mean comparisons were analyzed using Student's $t$ test $(P \leq 0.05)$ with SAS (SAS Institute, Inc., 1989, Cary, NC). The Pearson linear correlation technique was used for examining the relationships among the leaf gas exchange parameters and disease severity.

\section{RESULTS}

Anthracnose severity and AUAPC. The anthracnose severity on the leaves of the -Si-treated plants increased over time, reaching $90 \%$ at 10 dai (Fig. $1 \mathrm{~A}$ ). For the + Si-treated plants, the anthracnose progress was slow, and the severity was only $15 \%$ at 10 dai (Fig. 1A). For the + Si plants, the AUAPC was reduced by $86 \%$ compared with the - Si plants (Fig. 1B).

Leaf gas exchange. For the evaluations performed at both 8 and $12 \mathrm{~h}$, the $A, g_{\mathrm{s}}$, and $E$ values were lower on the $-\mathrm{Si}$ plants inoculated with $C$. sublineolum compared with the values obtained for the inoculated + Si plants at both 4 and 8 dai (Fig. 2). The decreases at 4 and 8 dai were, respectively, 31 and $60 \%$ for $A$, 34 and $61 \%$ for $g_{s}$, and 27 and $57 \%$ for $E$. For the noninoculated plants, there was no significant difference between the $-\mathrm{Si}$ and $+\mathrm{Si}$ treatments for the values of $A, g_{\mathrm{s}}$, and $E$. Furthermore, there was only significant difference for the $C_{\mathrm{i}} / C_{\mathrm{a}}$ ratio for the $-\mathrm{Si}$ and + Si treatments at 12:00 $\mathrm{h}$, regardless of the pathogen inoculation (Fig. 2). The correlation between the severity and $g_{\mathrm{s}}$ was negatively significant for the $+\mathrm{Si}$ plants (Table 1). As expected, the greatest $g_{\mathrm{s}}$ values for the $+\mathrm{Si}$ plants resulted in higher $E$ values (Fig. 2), a finding that was also verified by the positive correlation
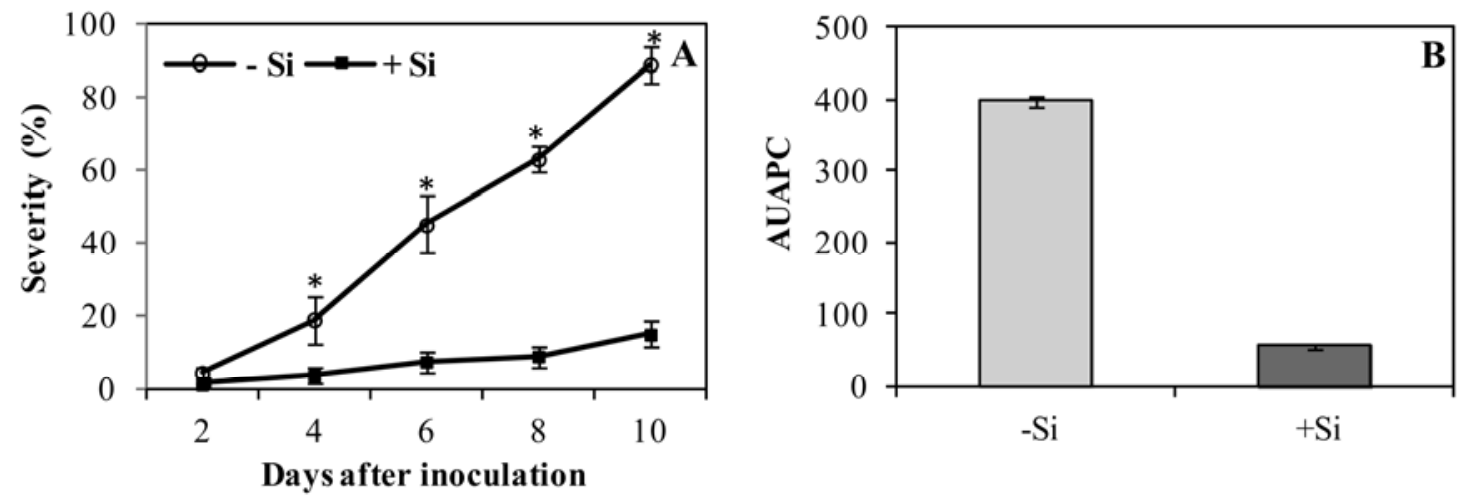

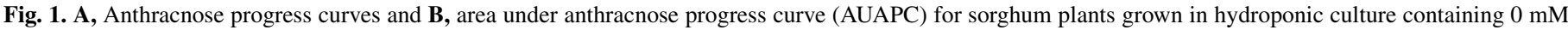

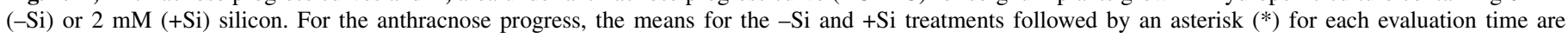
significantly different according to the Student's $t$ test $(P \leq 0.05)$. The error bars represent the standard error of the mean $(n=12)$. 
between $g_{\text {s }}$ and $E$ (Table 1 ). The $A$ parameter was negatively correlated with the disease severity and was positively correlated with the $g_{\text {s }}$ parameter (Table 1).

Enzymes activities. Overall, the enzyme activities tended to be higher for the $+\mathrm{Si}$ plants when compared with the $-\mathrm{Si}$ plants after infection by $C$. sublineolum. Significant increases were found for SOD (99\% at 4 dai; Fig. 3A), APX (33\% at 4 dai; Fig. 3B), CAT (138 and $101 \%$ at 4 and 8 dai, respectively; Fig. 3C) and GR (75\% at 8 dai; Fig. 3D).

EL, $\mathrm{H}_{2} \mathrm{O}_{2}$, and lipid peroxidation. The EL significantly increased by $47 \%$ (4 dai) and $26 \%$ (8 dai) on the leaves of the $-\mathrm{Si}$ plants compared with the leaves of the $+\mathrm{Si}$ plants (Fig. 4A). At 8 dai, the $\mathrm{H}_{2} \mathrm{O}_{2}$ concentration was significantly higher in the leaves of the $-\mathrm{Si}$ plants compared with the $+\mathrm{Si}$ plants (Fig. 4B). The MDA concentration significantly increased by 31 and $38 \%$ at 4 and 8 dai, respectively, for the $-\mathrm{Si}$ plants compared with the $+\mathrm{Si}$ plants (Fig. 4C).

\section{DISCUSSION}

Although the potential of $\mathrm{Si}$ to reduce the symptoms of anthracnose in sorghum has been reported by Resende et al. (38), the mechanisms involved currently remain elusive. Decreases in photosynthesis caused by pathogen infections have been well documented for several plant species $(8,14,40)$. In the present study, the values for the $A, g_{\mathrm{s}}$, and $E$ were reduced in the leaves of the -Si plants, which showed a greater anthracnose severity and, consequently, a higher AUAPC compared with the $+\mathrm{Si}$ plants. These results are corroborated by the negative correlations between anthracnose severity and $A, g_{\mathrm{s}}$, and $E$ parameters. It is known that one of the typical symptoms of anthracnose is the desiccation of the sorghum leaves (36); to avoid excessive water loss, the stomata of diseased leaves are closed to maintain a favorable water status, ultimately leading to a decrease in $E$. Indeed, decreases in the $E$ parameter are usually observed for leaf tissues infected with pathogens that cause stomatal closure, colonize the intercellular spaces, and sporulate via the stomata $(17,45)$

In addition to the observed reduction in the $g_{\mathrm{s}}$ value in the $-\mathrm{Si}$ plants, the reduction in the $E$ value may also have been the result of the massive colonization of the mesophyll cells by $C$. sublineolum, resulting in the wilting or substantial drying of the infected leaves. Bassanezi $(5,6)$ observed a decrease in the $E$

TABLE 1. Pearson correlation coefficients among the net carbon assimilation rate $(A)$, stomatal conductance to water vapor $\left(\mathrm{g}_{\mathrm{s}}\right)$, internal to ambient $\mathrm{CO}_{2}$ concentration ratio $\left(C_{\mathrm{i}} / C_{\mathrm{a}}\right)$, transpiration rate $(E)$, and anthracnose severity $(\mathrm{Sev})$ on the leaves of sorghum plants grown in hydroponic culture containing $0 \mathrm{mM}(-\mathrm{Si})$ or $2 \mathrm{mM}(+\mathrm{Si})$ silicon $^{\mathrm{a}}$

\begin{tabular}{llllll}
\hline Variables & $g_{\mathrm{s}}$ & $A$ & $C_{\mathrm{i}} / C_{\mathrm{a}}$ & $E$ & $\mathrm{Sev}$ \\
\hline$g_{\mathrm{s}}$ & - & $0.88^{*}$ & $0.74^{*}$ & $0.88^{*}$ & $-0.60^{*}$ \\
$A$ & $0.95^{*}$ & - & $0.41^{*}$ & $0.87^{*}$ & $-0.41^{*}$ \\
$C_{\mathrm{i}} / C_{\mathrm{a}}$ & $0.80^{*}$ & $0.60^{*}$ & - & $0.57^{*}$ & $-0.77^{*}$ \\
$E$ & $0.93^{*}$ & $0.88^{*}$ & $0.75^{*}$ & - & $-0.55^{*}$ \\
Sev & $-0.59^{*}$ & $-0.40^{*}$ & $-0.81^{*}$ & $-0.52^{*}$ & -
\end{tabular}

a The values above and below the diagonal are the measurements made at 8 and $12 \mathrm{~h}$, respectively. * indicates significance at $1 \%$ probability according to the Student's $t$ test.
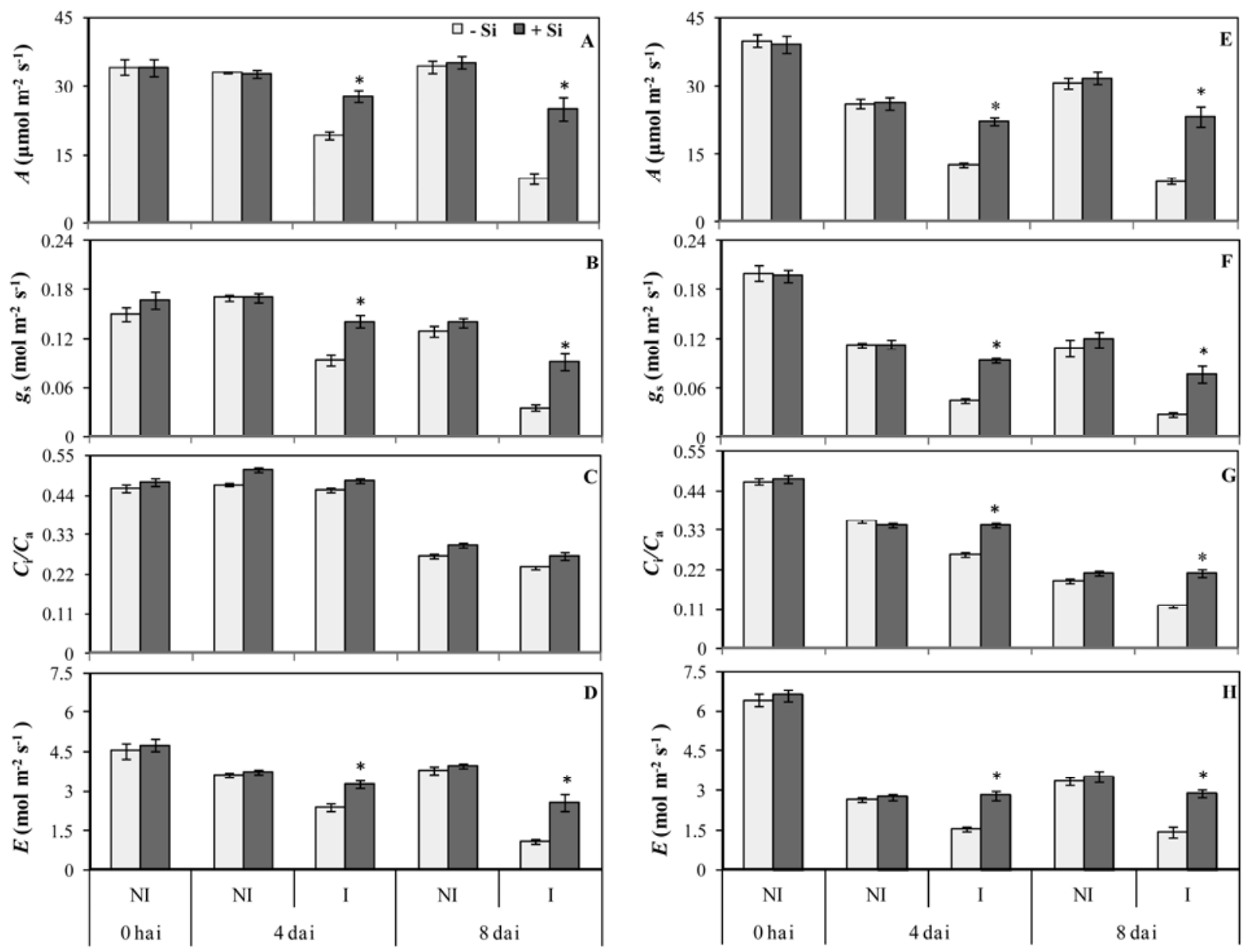

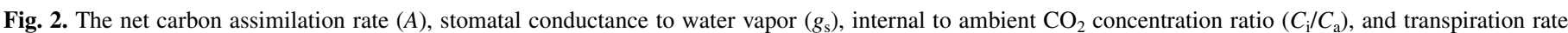
$(E)$ determined at $8 \mathrm{~h}(\mathbf{A}, \mathbf{B}, \mathbf{C}$, and $\mathbf{D})$ and $12 \mathrm{~h}(\mathbf{E}, \mathbf{F}, \mathbf{G}$, and $\mathbf{H})$ for the leaves of sorghum plants grown in hydroponic culture containing $0 \mathrm{mM}(-\mathrm{Si})$ or $2 \mathrm{mM}(+\mathrm{Si})$ silicon and noninoculated (NI) or inoculated (I) with Colletotrichum sublineolum. The means for the $-\mathrm{Si}$ and $+\mathrm{Si}$ treatments followed by an asterisk (*) for each evaluation time are significantly different according to the Student's $t$ test $(P \leq 0.05)$. The error bars represent the standard error of the mean $(n=20)$. 
parameter of common bean leaves with anthracnose due to stomatal closure and noted that reductions in $g_{\text {s }}$ were associated with lower $C_{\mathrm{i}}$ values, suggesting that stomatal constraints were the main limiting factors for $\mathrm{CO}_{2}$ assimilation in the diseased leaves. In the present study, however, despite the positive correlation between $A$ and $g_{\mathrm{s}}$, which may suggest stomatal limitations for photosynthesis, the $A$ parameter was positively correlated with the $C_{\mathrm{i}} / C_{\mathrm{a}}$ ratio. Therefore, nonstomatal limitations of the photosynthetic machinery could also be associated with the lower values of $A$, particularly for the - Si plants.

Even though the anthracnose severity was low from 4 to 6 dai, a dramatic reduction in the value of $A$ was noted, indicating that the sorghum physiology was impaired due to the $C$. sublineolum infection, even under a low disease severity. In addition to procuring carbohydrates and nutrients from healthy tissues, this pathogen secretes nonspecific toxins and lytic enzymes that may diffuse into the leaf tissues that are not yet colonized by the fungus (13). Taken together, this information may explain why the leaf area affected by the pathogen is much greater than the area that is actually colonized (8). Similarly, Meyer et al. (32) reported that $C$. lindemuthianum caused stomatal closure in the green areas of bean leaves that were apparently healthy, reducing the photosynthesis of the entire leaf even under a lower disease severity.

Considering that carbon fixation, the usual main sink for the absorbed light in the chloroplasts, was slightly reduced, particularly in the -Si plants infected with $C$. sublineolum, the resulting surplus excitation energy must be dissipated to avoid photooxidative damage to the leaf tissues. Indeed, the photosynthetic reduction of $\mathrm{O}_{2}$, via photorespiration and the Mehler-peroxidase pathway, has been proposed to provide photoprotection by acting as a sink for excitation energy in the photosynthetic apparatus (50). However, this leads to the production of ROS, especially superoxide and $\mathrm{H}_{2} \mathrm{O}_{2}(9,44)$. Therefore, increases in the capacity of the antioxidant system are required to scavenge the ROS, as was observed in the $+\mathrm{Si}$ sorghum plants but not in their $-\mathrm{Si}$ counterparts after $C$. sublineolum infection. In $+\mathrm{Si}$ plants, there were increases in the activity of SOD, which catalyses the dismutation of superoxide, producing $\mathrm{O}_{2}$ and $\mathrm{H}_{2} \mathrm{O}_{2}$. It should be noted that $\mathrm{Si}$ is not capable to induce ROS by itself. It is known that $\mathrm{Si}$ expresses its potential in the presence of biotic stress (ex. pathogen infection) and it is not toxic to either plants or pathogens (15). Thus, a higher SOD activity could have accounted for the protection against oxidative stress in the leaves of the plants supplied with $\mathrm{Si}$. In any case, the expected higher production of $\mathrm{H}_{2} \mathrm{O}_{2}$ with an increasing SOD activity should be coupled with the rapid removal of $\mathrm{H}_{2} \mathrm{O}_{2}$ by other scavenging systems, thus minimizing the $\mathrm{H}_{2} \mathrm{O}_{2}$ and hydroxyl radical cytotoxicity (37). In fact, increases in the activities of CAT, APX, and GR were observed, which may have been translated into the effective removal of $\mathrm{H}_{2} \mathrm{O}_{2}$ from the infected leaf tissues. Therefore, based on the data from the present study, the antioxidant system of the $+\mathrm{Si}$ plants probably functioned at increased rates to prevent the accumulation of ROS, ultimately resulting in a lower $\mathrm{EE}$ and MDA concentrations in these plants during $C$. sublineolum infection. In contrast, the higher $\mathrm{H}_{2} \mathrm{O}_{2}$ concentration (and probable rise in other ROS) during the infectious process of $C$. sublineolum in the -Si plants was not accompanied by an increased antioxidant capacity and resulted in photooxidative damage, as evidenced by the considerable increase in the MDA concentration. Such an increase in photooxidation may result in the decreased membrane integrity that may have led to the enhanced EE, as suggested by Lima et al. (27). It must also be emphasized that these damages would have further contributed to the impaired carbon fixation in the - Si plants.

In addition to the role of $\mathrm{Si}$ in enhancing the activities of the detoxifying enzymes involved in ROS removal, the complexation of both $\mathrm{Fe}(\mathrm{III})$ and $\mathrm{Fe}$ (II) with tannins and proanthocyanidins may prevent the generation of highly toxic hydroxyl radicals $(2,47)$. Notably, 3-deoxianthocyanidin, a phytoalexin belonging to the
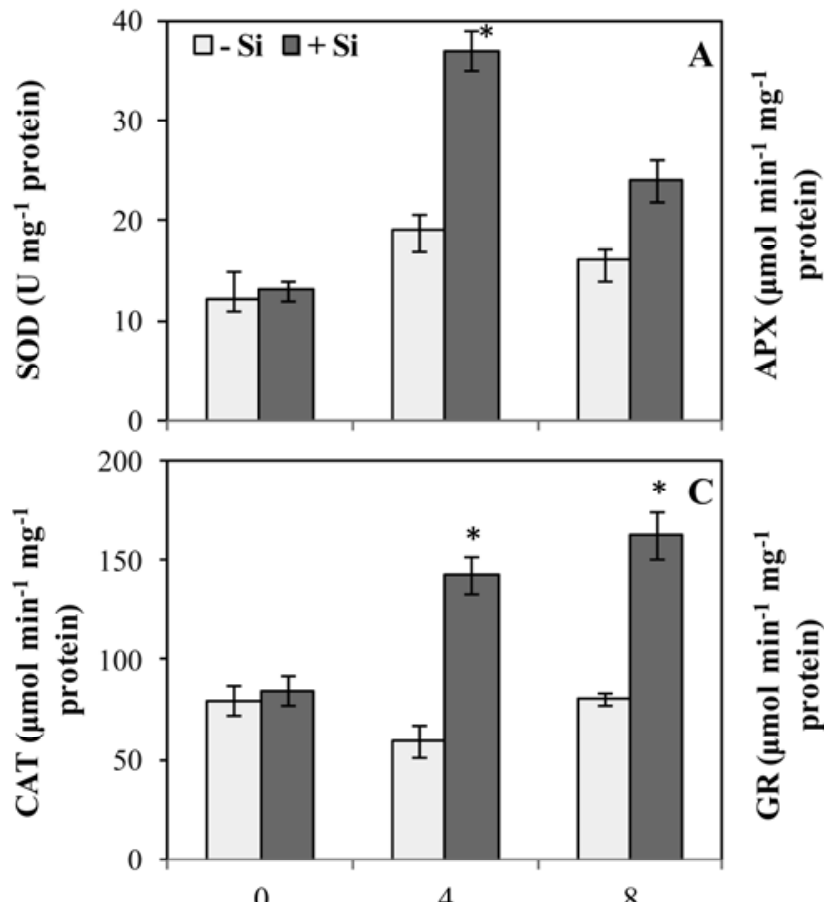

Days after inoculation
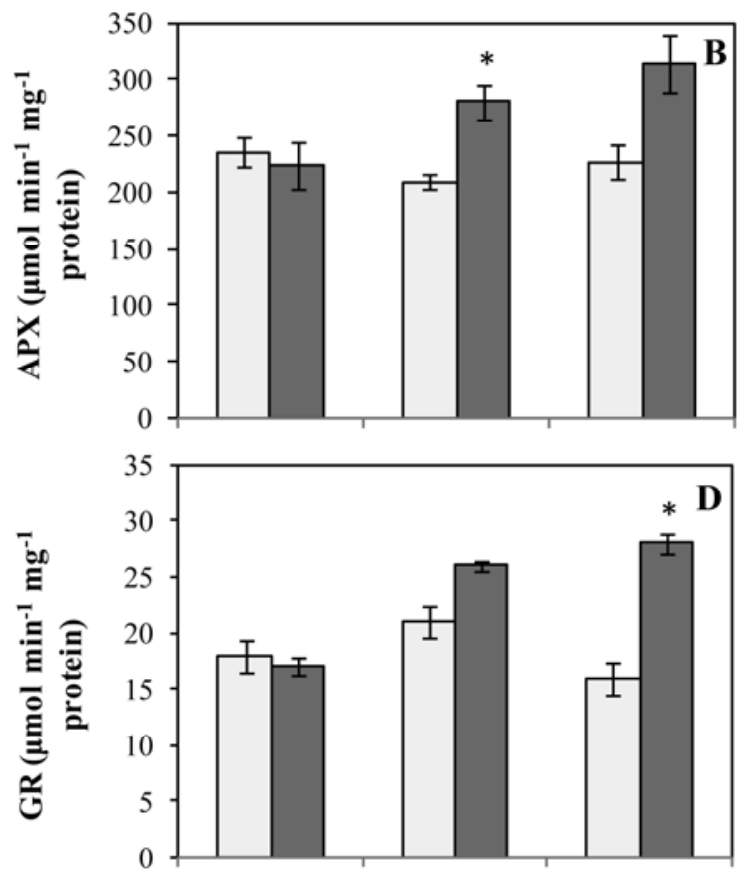

0

Days after inoculation

Fig. 3. The activities of A, superoxide dismutase (SOD), B, ascorbate peroxidase (APX), C, catalase (CAT), and D, glutatione reductase (GR) in the leaves of sorghum plants grown in hydroponic culture containing $0 \mathrm{mM}(-\mathrm{Si})$ or $2 \mathrm{mM}(+\mathrm{Si})$ silicon after inoculation with Colletotrichum sublineolum. The means for the $-\mathrm{Si}$ and $+\mathrm{Si}$ treatments followed by an asterisk $(*)$ for each evaluation time are significantly different according to the Student's $t$ test $(P \leq 0.05)$. The error bars represent the standard error of the mean $(n=12)$. 
flavonoid class, is synthesized at high amounts in sorghum leaves as a defense mechanism against $C$. sublineolum infection (28). Despite the absence of available information linking the effect of $\mathrm{Si}$ with the production of 3-deoxianthocyanidin, it is plausible to speculate that $\mathrm{Si}$ might have an additional role in reinforcing the antioxidant system of diseased plants via an increased 3-deoxianthocyanidin concentration, so that the cellular damage caused by $C$. sublineolum infection may be properly halted.

The increases in lipid peroxidation observed in the present study are in agreement with the results from other studies. Von Gönner et al. (48) reported increased lipid peroxidation during the early colonization phase of oat leaf tissues by the necrotrophic fungi, Drechslera avenae and D. siccans, which use ROS to destroy the leaf cells, leading to necrosis. In the present study, the lower severity of anthracnose for plants supplied with Si was the result of a lower colonization of the leaf tissues by $C$. sublineolum in association with reduced damage to the integrity of the cell membranes. It should be noted that Si plays an important role in maintaining the integrity of the cell membranes of plants exposed to different abiotic stresses, as has been observed for barley plants supplied with $\mathrm{Si}$ and under salt stress, which displayed reduced EL and lower MDA concentrations $(25,26)$.

In conclusion, the results of this study clearly demonstrated that Si can affect the physiology of sorghum plants, particularly when
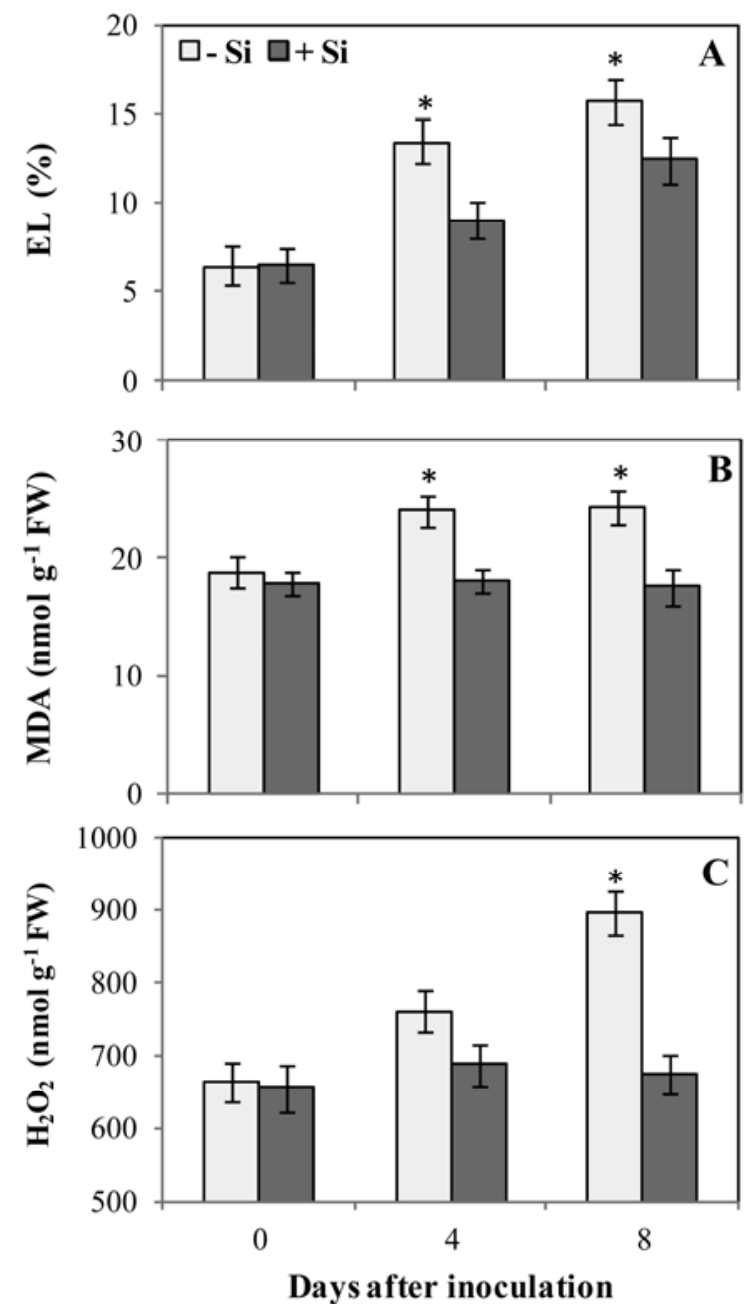

Fig. 4. Electrolyte leakage (EL), concentration of malondialdehyde (MDA), and concentration of hydrogen peroxide $\left(\mathrm{H}_{2} \mathrm{O}_{2}\right)$ in the leaves of sorghum plants grown in hydroponic culture containing $0 \mathrm{mM}(-\mathrm{Si})$ or $2 \mathrm{mM}(+\mathrm{Si})$ silicon after inoculation with Colletotrichum sublineolum. The means for the $-\mathrm{Si}$ and $+\mathrm{Si}$ treatments followed by an asterisk $(*)$ for each evaluation time are significantly different according to the Student's $t$ test $(P \leq 0.05)$. The error bars represent the standard error of the mean $(n=12)$. FW $=$ fresh weight. the plants are infected with $C$. sublineolum. It was found that the mechanism acted through the maintenance of carbon fixation, in addition to the enhancement of the antioxidant system, which resulted in increased ROS scavenging and, ultimately, reduced damage to cell membranes. Nevertheless, yet unknown mechanisms by which Si may afford protection against $C$. sublineolum infection should also be taken into account; thus, further research is merited.

\section{ACKNOWLEDGMENTS}

F. A. Rodrigues and F. M. DaMatta thank CNPq for their fellowship. R. S. Resende was supported by CNPq. We thank CAPES, CNPq, and FAPEMIG for the financial support.

\section{LITERATURE CITED}

1. Ali, M. E. K., and Warren, H. L. 1992. Anthracnose of sorghum. Pages 203-208 in: Sorghum and Millets Diseases: A Second World Review. W. A. J. De Milliano, R. A. Frederiksen, and G. D. Bengston, eds. ICRISAT, Patancheru, India.

2. Andrade, R. G., Ginani, J. S., Lopes, G. K. B., Dutra, F., Alonso, A., and Hermes-Lima, M. 2006. Tannic acid inhibits in vitro iron-dependent free radical formation. Biochimie 88:1287-1296.

3. Apel, K., and Hirt, H. 2004. Reactive oxygen species: Metabolism, oxidative stress, and signal transduction. Annu. Rev. Plant Biol. 55:373-399.

4. Asada, K. 1999. The water-water cycle in chloroplasts: Scavenging of active oxygen and dissipation of excess photons. Annu. Rev. Plant Physiol. Plant Mol. Biol. 50:601-639.

5. Bassanezi, R. B., Amorim, L., and Bergamin Filho, A. 2000. Análise das trocas gasosas em feijoeiro com ferrugem, mancha angular e antracnose. Fitopatol. Bras. 25:643-650.

6. Bassanezi, R. B., Amorim, L., Bergamin Filho, A., and Berger, R. D. 2002. Gas exchange and emission of chlorophyll fluorescence during the monocycle of rust, angular leaf spot and anthracnose on bean leaves as a function of their trophic characteristics. J. Phytopathol. 150:37-47.

7. Bastiaans, L. 1991. Ratio between virtual and visual lesion size as a measure to describe reduction in leaf photosynthesis of rice due to leaf blast. Phytopathology 81:611-615.

8. Berger, S., Sinha, A. K., and Roitsch, T. 2007. Plant physiology meets phytopathology: Plant primary metabolism and plant-pathogen interactions. J. Exp. Bot. 58:4019-4026.

9. Biehler, K., and Fock, H. P. 1996. Evidence for the contribution of the Mehler peroxidase reaction in dissipation of excess electrons in drought stressed wheat. Plant Physiol. 112:265-272.

10. Bolton, M. D. 2009. Primary metabolism and plant defense fuel for the fire. Mol. Plant-Microbe Interact. 22:487-497.

11. Bradford, M. N. 1976. A rapid and sensitive method for the quantitation of microgram quantities of protein utilizing the principle of protein-dye binding. Anal. Biochem. 72:248-254.

12. Cakmak, L., and Horst, W. J. 1991. Effect of aluminum on lipid peroxidation, superoxide dismutase, catalase, and peroxide activity in root tip of soybean (Glycine max). Plant Physiol. 83:463-468.

13. Casela, C. R., Pinto, N. F. J. A., Oliveira, E., and Ferreira, A. S. 1997. Doenças do Sorgo. Pages 1025-1064 in: Controle de Doenças de Plantas. L. Zambolim and F. X. R. Vale, eds. Universidade Federal de Viçosa, Minas Gerais, Brazil.

14. Chou, H., Bundock, N., Rolfe, S. A., and Scholes, J. D. 2000. Infection of Arabidopsis thaliana leaves with Albugo candida (white blister rust) causes a reprogramming of host metabolism. Mol. Plant Pathol. 1:99-113.

15. Datnoff, L. E., Rodrigues, F. A., and Seebold, K. W. 2007. Silicon and plant disease. Pages 233-243 in: Mineral Nutrition and Plant Disease. L. E. Datnoff, W. H. Elmer, and D. M. Huber, eds. The American Phytopathological Society, St. Paul, MN.

16. Dhingra, O. D., and Sinclair, J. B. 1995. Basic Plant Pathology Methods. 2nd ed. CRC Press, Boca Raton, FL.

17. Duniway, J. M., and Durbin, R. D. 1971. Some effects of Uromyces phaseoli on the transpiration rate and stomatal response of bean leaves. Phytopathology 61:114-119.

18. Frederiksen, R. A. 2000. Compendium of Sorghum Diseases. The American Phytopathological Society, St. Paul, MN.

19. Gay, C., and Gebicki, J. M. A. 2000. Critical evaluation of the effect of sorbitol on the ferricxylenol orange hydroperoxide assay. Anal. Biochem. 284:217-220.

20. Giannopolitis, C. N., and Ries, S. K. 1977. Superoxide dismutases. I. Occurrence in higher plants. Plant Physiol. 59:309-314.

21. Gong, H., Chen, K., Chen, G., Wang, S., and Zhang, C. 2003. Effects of 
silicon on the growth of wheat and its antioxidative enzymatic system. Chin. J. Soil Sci. 34:55-57.

22. Havir, E. A., and McHale, N. A. 1989. Enhanced-peroxidatic activity in specific catalase isozymes of tobacco, barley, and maize. Plant Physiol. 91:812-815.

23. Hoagland, D. R., and Arnon, D. I. 1950. The water culture method for growing plant without soil. Calif. Agric. Exp. Stn. Circ. 347:1-32.

24. Kuo, M. C., and Kao, C. H. 2003. Aluminum effects on lipid peroxidation and antioxidative enzyme activities in rice leaves. Biol. Plant. 46:149-152.

25. Liang, Y. C., Chen, Q., Liu, Q., Zhang, W. H., and Ding, R. X. 2003. Exogenous silicon $(\mathrm{Si})$ increases antioxidant enzyme activity and reduces lipid peroxidation in roots of salt-stressed barley (Hordeum vulgare L.). J. Plant Physiol. 160:1157-1164.

26. Liang, Y. C., Zhang, W. H., Chen, Q., Liu, Y. L., and Ding, R. X. 2006. Effect of exogenous silicon ( $\mathrm{Si}$ ) on $\mathrm{H}^{+}$-ATPase activity, phospholipids and fluidity of plasma membrane in leaves of salt-stressed barley (Hordeum vulgare L.). Environ. Exp. Bot. 57:212-219.

27. Lima, A. L. S., DaMatta, F. M., Pinheiro, H. A., Totola, M. R., and Loureiro, M. E. 2002. Photochemical responses and oxidative stress in two clones of Coffea canephora under water deficit conditions Environ. Exp. Bot. 47:239-247.

28. Lo, S. C., De Verdier, K., and Nicholson, R. L. 1999. Accumulation of 3deoxyanthoxyanidin phytoalexins and resistance to Colletotrichum sublineolum in sorghum. Physiol. Mol. Plant Pathol. 55:263-273.

29. Ma, J. F., and Takahashi, E. 2002. Soil, Fertilizer, and Plant Silicon Research in Japan. Elsevier Science, Amsterdam.

30. Ma, J. F., and Yamaii, N. 2008. Functions and transport of silicon in plants. Cell. Mol. Life Sci. 65:3049-3057.

31. Mateo, A., Muhlenbock, P., Rusterucci, C., Chang, C. C., Miszalski, Z., Karpinska, B., Parker, J. E., Mullineaux, P. M., and Karpinski, S. 2004. LESION SIMULATING DISEASE 1 is required for acclimation to conditions that promote excess excitation energy. Plant Physiol. 136: 2818-2830.

32. Meyer, S., Saccardy-Adji, K., Rizza, F., and Genty, B. 2001. Inhibition of photosynthesis by Colletotrichum lindemuthianum in bean leaves determined by chlorophyll fluorescence imaging. Plant Cell Environ. 24:947955.

33. Mittler, R. 2002. Oxidative stress, antioxidants and stress tolerance. Trends Plant Sci. 7:405-410.

34. Moller, I. M. 2001. Plant mitochondria and oxidative stress: Electron transport, NADPH turnover, and metabolism of reactive oxygen species. Annu. Rev. Plant Physiol. Plant Mol. Biol. 52:561-591.

35. Nakano, Y., and Asada, K. 1981. Hydrogen peroxide is scavenged by ascorbate-specific peroxidase in spinach chloroplasts. Plant Cell Physiol. 22:867-880.

36. Pande, S., Mughogho, L. K., Bandyopadhyay, R., and Karunakar, R. I. 1991. Variation in pathogenicity and cultural characteristics of sorghum isolates of Colletotrichum graminicola in India. Plant Dis. 75:778-783.
37. Perl, A., Perl-Treves, R., Galili, S., Aviv, D., Shalgi, E., Malkin, S., and Galun, E. 1993. Enhanced oxidative-stress defense in transgenic potato expressing tomato $\mathrm{Cu} / \mathrm{Zn}$ superoxide dismutases. Theor. Appl. Genet. 85:568-576

38. Resende, R. S., Rodrigues, F. A., Soares, M. J., and Casela, C. R. 2009. Influences of silicon on some components of resistance to anthracnose in susceptible and resistant sorghum lines. Eur. J. Plant. Pathol. 124:533541.

39. Scandalios, J. G. 1993. Oxygen stress and superoxide dismutases. Plant Physiol. 101:7-12.

40. Scholes, J., and Rolfe, S. A. 1996. Photosynthesis in localized regions of oat leaves infected with crown rust (Puccinia coronata): Quantitative imaging of chlorophyll fluorescence. Planta 199:573-582.

41. Shaner, G., and Finney, R. E. 1977. The effect of nitrogen fertilization on the expression of slow-mildewing resistance in Knox wheat. Phytopathology 67:1051-1056.

42. Sharma, H. C. 1978. Screening of sorghum for leaf-disease resistance in India. Sorghum Diseases: A World Review. Pages 249-264 in: Proceedings of the International Workshop on Sorghum Diseases. R. J. Williams, R. A. Frederiksen, and L. K. Mughogho, eds. International Crop Research Institute for the Semi-Arid Tropic. Patancheru, Andhra Pradesh, India.

43. Sherrif, C., Whelan, M. J., Arnold, G. M., and Bailey, J. A. 1995. rDNA sequence analysis confirms the distinction between Colletotrichum graminicola and C. sublineolum. Mycol. Res. 99:475-478.

44. Smirnoff, N. 1995. Antioxidant systems and plant response to the environment. Pages 217-243 in: Environment and Plant Metabolism: Flexibility and Acclimation. N. Smirnoff, ed. BIOS Scientific Publishers, Oxford.

45. Spotts, R. A., and Ferree, D. C. 1979. Photosynthesis, transpiration and water potential of apple leaves infected by Venturia inaequalis. Phytopathology 69:717-719.

46. Sutton, B. C. 1980. Fungi imperfect with pycnidia, acervuli and stromata. Pages 386-388 in: The Coelomycetes. CMI, Kew, Surrey, England.

47. Toda, S. 2005 Antioxidative effects of polyphenols in leaves of Houttuynia cordata on protein fragmentation by copper-hydrogen peroxide in vitro. J. Med. Food 8:266-268.

48. Von Gönner, M., Schlösser, E., and Neubacher, H. 1993. Evidence from electron-spin resonance for the formation of free radicals during infection of Avena sativa by Drechslera spp. Physiol. Mol. Plant Pathol. 42:405-412.

49. Warren, H. L. 1986. Leaf anthracnose. Pages 10-11 in: Compendium of Sorghum Diseases. R. A. Frederiksen, ed. The American Phytopathological Society, St. Paul, MN.

50. Wihelm, C., and Selmar, D. 2011. Energy dissipation is an essential mechanism to sustain the viability of plants: The physiological limits of improved photosynthesis. J. Plant Physiol. 168:79-87.

51. Zhu, Z. J., Wei, G. Q., Li, J., Qian, Q. Q., and Yu, J. Q. 2004. Silicon alleviates salt stress and increases antioxidant enzymes activity in leaves of salt-stressed cucumber (Cucumis sativus L.). Plant Sci. 167:527-533. 